\title{
Transforming Cape Vert Informal Settlements
}

\author{
Miguel Amado 1,*(1), Francesca Poggi 2 (i), Adriana Martins ${ }^{3}$, Nuno Vieira ${ }^{3}$ \\ and Antonio Ribeiro Amado 4 \\ 1 Civil Engineering Research and Innovation for Sustainability (CERIS), Instituto Superior Tecnico, \\ Universidade de Lisboa, Av. Rovisco Pais 1, 1049-001 Lisboa, Portugal \\ 2 Centro Interdisciplinar de Ciências Sociais (CICS.NOVA), Faculdade de Ciências Sociais e Humanas \\ Universidade Nova de Lisboa, 1069-061 Lisboa, Portugal; f.poggi@fcsh.unl.pt \\ 3 GEOTPU.LAB, Instituto Superior Técnico, Universidade de Lisboa, Av. Rovisco Pais 1, \\ 1049-001 Lisboa, Portugal; afs.martins@campus.fct.unl.pt (A.M.); nf.vieira@campus.fct.unl.pt (N.V.) \\ 4 CIAUD, Faculdade de Arquitectura de Lisboa, Universidade de Lisboa, R. Sá Nogueira, \\ 1349-063 Lisboa, Portugal; ar.amado@campus.fct.unl.pt \\ * Correspondence: miguelpamado@tecnico.ulisboa.pt
}

Received: 5 June 2018; Accepted: 16 July 2018; Published: 23 July 2018

\begin{abstract}
The lack of land ownership databases in developing countries has influenced inhabitants of these countries to occupy public lands. This situation has resulted in areas of informal housing, commerce, and agriculture, ultimately creating new informal settlements, which are becoming a serious problem in developing countries. These informal settlements contain inhabitants settled on public land without any infrastructure and against the landowner's wishes. This process results in uncontrolled land occupation that promotes new informal areas without any proper urban utilities, positioned in risky areas, where the minimum requirements for healthy living are not being met. In some cases, this incentivizes an informal economy. Building a cadastral map in informal settlement areas is fundamental to supporting the future transformation of illegal areas, and in regulating the occupation of new subdivisions and new expansion areas. In this paper, we present a methodology developed to support the management of informal settlement areas. The method we used has the potential for replication so that it can be adapted to multiple types of informal settlements, as can the model used to register the land tenure. The model was developed using a series of qualitative and quantitative data that determine the identification and classification of buildings, along with a physical and functional description. A Geographic Information System, an initial survey of existing land titles of possession, and public proposals to develop new expansion areas were used to develop the model. A case study is presented where the land management model was implemented in Chã da Caldeiras in Ilha do Fogo, which is an informal settlement in Cape Verde. The proposal created using the results was accepted by the population and local authorities.
\end{abstract}

Keywords: sustainability; urban planning; parametric model; informal settlements; geographic information system (GIS)

\section{Introduction}

Informal settlements represent a large percentage of urban areas in developing countries [1]. These settlements are generally composed of buildings without a construction license or legal or technical documentation, which promotes the destruction and contamination of land over time, hinders planning activity in the territory, and prevents the development of new opportunities. One of the common aspects of these settlements is the social segregation of the population, including social, physical, and spatial segregation between settlements and the surrounding formal areas [2]. Several authors have offered differing perspectives [3-6] on informal settlements, namely in terms of 
the main aspects of their creation and features. Abrams [3] argues that the growth of such settlements is due to the quest for shelter in urban areas, that is, the need to find shelter given the lack of efficient formal channels to such end. Furthermore, the same author claims that this conquest is accomplished by the "law of force" (squatters) or the "force of law", the latter related to the absence of an alternative solution provided by governments. In the same vein, Payne [4] states that the growth of informal settlements is inevitable in developing countries, [7]. International thinking about these settlements has been changing, given the urgent need to develop solutions for this immediate problem. For many years, informal settlements were only an urban problem, and the demolition of these areas was promoted, along with relocating inhabitants into formal areas as the solution.

However, this perspective has been changing, not only because relocation has become financially unenforceable but also because these settlements have begun to be recognized as social and economic hubs, due to having social and economic capital that should be encouraged to grow $[1,8]$. However, informal settlements without ownership or land management have caused problems in terms of public spaces and utilities, transportation, hygiene, the environment, and organization and legal land solutions [2,9-13]. As such, introducing or improving land administration systems to achieve the sustainable development of those settlements is essential.

As stated in the 2030 Agenda for Sustainable Development, land should be protected and sustainably managed for social cooperation, security, and order $[2,10,14]$. The existence of a land administration system allows the identification, registration, and sharing of information about the use of land according to land policies [15-17]. Land policy is known as the way of governance approach to land issues, its access, administration and use [15,18-20]. An effective land administration system is an essential element to ensure the correct use of land and sustainable development in terms of a social, legal, economic, environmental, and technical framework [21-24].

One of the land administration system elements is the cadastre. A record is a public data register related to properties and ownership of the land-including rights, restrictions, and responsibilities - which is methodically organized based on a survey of land boundaries $[18,25,26]$ and legal title of possession. The cadastral system helps create an efficient land market and effective land-use administration, and transparently promotes the economic development, social cohesion, and sustainable development of a society [22,27-30]. Furthermore, some authors consider the transformation of settlements a risk because the return on investment cannot be determined, however the goal of providing a better quality of life to the inhabitants of these areas necessitates the implementation of actions for stimulating the investment into and the regulation of land occupation.

Therefore, in this paper, a methodology for a new land management system for informal settlement areas was created, developed, and applied. The methodology is based on four fundamental steps: analysis and survey of existent land occupation, design of a parametric model, topologic definition of new parcels, and development of the cadastral model solution. These steps are described in detail in the next section. Chã das Caldeiras, located in Ilha do Fogo, Cape Verde, was used as a good example of an informal settlement without land registration and a regular cadastre. Given this context, Chã de Caldeiras was selected as the case study area in which to apply the developed methodology, which is presented in the third part of this paper. By applying this methodology, the compact urban area was determined. This information could be used to ensure minimum living conditions and balanced social support for the inhabitants of different land uses, and to ensure equity to all stakeholders through a transparent and fair process for both the population of Fogo Island and the State of Cape Verde. The results obtained approval from the Government of Cape Verde, which was the Municipal Entity involved in the plan. The public participation of people influenced by the plan led to a growing relationship between different sectors of the population in terms of decision-making.

\section{Methodology}

The creation of a cadastral model for an informal settlement must ensure the limits of the area and the dimensions, ownership, and title of possession of existing parcels in the settlement. The proposed 
cadastral model was defined by a series of data that systematized the identification and uses of the parcels and buildings, of urban, rural, and mixed origin, their physical and functional descriptions, and their occupants. Additionally, the cadastral model had to contain a database to support the definition of new parcels and to inform the design of the expansion of the settlement area.

\subsection{Step 1: Analysis and Survey of Existent Land Occupation}

The main goal was to create a future cadastral record, and a basis upon which to analyse the settlements' topologic physical, social, economic, and environmental characteristics. First, a topographic survey map of this area, which was necessary for the creation of the database, was created. This database was composed of raster images that provide a visual backdrop, while the polygons of the buildings or parcels allow the assignment of a code to each parcel.

A land parcel is the basic unit in the cadastral system. A singular code is assigned to each parcel, and listed on a cadastral survey plan along with its dimensions and geographic position. The preparation of the register of existing occupation was based on on-site work that involved the mapping and characterizing of all of the existing buildings and their limits, as well as the surrounding areas inside the settlement limits. This process and type of system is only credible if the entire process is followed with the participation of local community [7,31-33]). The cadastral surveys require that land occupants be consulted to identify and localize the cadastral register boundaries. In addition to the parcel limits, collecting all the existing physical-spatial data is necessary, such as topographic and natural features and any additional characteristics, including water standpipes or latrine structures. Collecting socio-economic data is also required, including the chief of each family or household name, and the number of people per dwelling.

The survey of the existing land use must be rigorous. Identifying common elements in the land use survey is necessary, as correct functional and activity identification of the territory is required to create an urban model that reflects reality according the occupation area, in both the present and for future transformations. All the collected data should be subsequently computerized, using a Geographic Information System (GIS) and a database. Many studies $[1,15,18,31]$ have highlighted the importance of using GIS for defining and supporting future land development, including management and planning decisions. All the collected data should be complemented with a set of environmental, morphologic, legal, risk, and social-economic analyses, including the identification of the relationships between the quantitative and qualitative data and their overlap, achieved by using GIS.

A correct analysis and interpretation of the collected data, such as traditional social behaviours, are essential to achieving a logical and fair solution according to the reality of the settlement.

\subsection{Step 2: Design the Parametric Model}

Step 2 was based on the evaluation of all the physical components of the existing occupation of the settlement, and of the urban and rural living patterns that were identified in the first step. After understanding the structure, composition, and profile of the analysed community, we identified the parametric elements of the multiple existing parcels. Those elements created the base element that allowed the identification of the occupation pattern type. Additionally, the relationship between the number of family elements and the activities undertaken in the housing or parcel helped to establish a referential pattern for the future transformation of the informal settlement.

Given this information, the resulting parametric model aids the conceptualization of a new parcel typology that, after discussion with the population, could be implemented in the identified intervention areas to create a participative process of transformation [7]. These parameters were also essential for transforming the existing land use into a regular urban design. The parcel design had to be adjusted to guarantee areas for infrastructure channels and public spaces. These parameters should lead to fair and participatory adjustments of the occupied areas to fulfil the needs of the population. 


\subsection{Step 3: Definition of New Parcels}

The objective of Step 3 was to implement additional parcels in the intervention area, to sustainably and inclusively achieve urban transformation of the informal settlement. One part of the urban planning process involves an urban land tenure solution. This is an organised method where the structure of the parcel boundaries is modified, but land ownership is unaltered. Urban land consolidation has been increasingly used in multiple countries as an instrument of urban development $[1,2,18,27,34]$ and to establish a base for a future tax system.

In a planning process like that presented, addressing three different situations is required: (1) the potential relocation of a building, when the identified characteristics represent a potential restraint, putting the building in a risk classification; (2) the necessity of promoting a network of infrastructures within the settlement; and (3) identifying the needs of the population in terms of services, equipment, and areas required. The last two points could impact the parcels or the existing buildings. In the transformation of an informal settlement, it is essential to consider the fundamental characteristics of the number of existing people living in those settlements, and their individual or collective needs during the planning process.

Therefore, through the calculations completed in the second step, different typologies were defined with the goal of transforming and improving the living conditions to include better urban spaces and infrastructure. The description of the typology to be applied to the new parcels should be presented in a map that outlines the delimitation of the new parcels, in order to create a fair proposal for land occupation.

\subsection{Step 4: Development of the Cadastral Model}

In Step 4, after defining the new occupation model of the intervention area, registering all the parcels is necessary-including existing, new, and transformed parcels, using the cadastre that provides a complete list and documentation of the parcels possessors' rights and responsibilities. The parcels should be identified and assigned systematic codes (numbers and/or letters) to define the administrative composition. Some data are indispensable in a cadastral frame; alongside the parcel code, the geodesic coordinates, multiple dimensions, use, and other information must be recorded. In addition to the data that characterize the different parcels, calculating the urban parameters is also necessary to legislate the occupation, the urban development phases, and the responsibilities. The cadastral model should be registered in a map that includes legal boundaries, the respective urbanistic parameters, and cartesian coordinates frames. These three elements geographically and geometrically define the polygons of the transformed land and the new parcels with their reference codes.

\section{Case Study}

The study area is outlined in red in Figure 1, and depicts the informal settlement area of Chã das Caldeira located on Ilha (Island) do Fogo, at Cape Verde. The Chã das Caldeiras settlement is located in the Natural Park of Fogo (Parque Natural do Fogo) and is classified as a rural area. The settlements are situated in the interior of the volcano area, occupying an area of 57.49 ha of public land. The remarkable Pico's Volcano, a striking landscape feature of the area, is located near this settlement. The most recent eruption event was at the end of 2014 and affected the entire population of Chã das Caldeiras, with hugely negatively impacts on housing, tourist facilities, and agriculture areas.

The Chã das Caldeiras informal settlement is divided into two smaller parts: Bangaeira and Portela. The area has 231 buildings, with the majority being single family habitations with a total population of 675 people. The dominant activities in this settlement are agriculture and livestock. To provide this population with the basic infrastructure required for proper living conditions, reorganising the urban areas was essential. To reach this goal, we created a methodology to identify the existing parcels and to promote their reorganisation. 
In this section, we present and explain the proposed method, including the application of the four steps to the case study of Chã das Caldeiras.

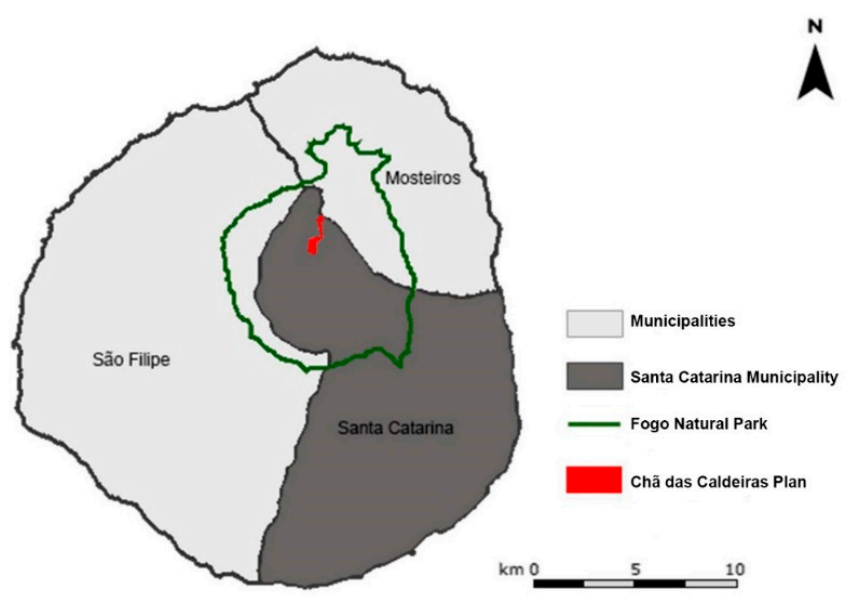

Figure 1. Location of Chã das Caldeiras, Fogo Island, Cape Verde.

\subsection{Application of Step 1: Analysis and Survey of Existing Land Occupation}

The main objective for collecting data regarding the two parts of the informal settlement was to construct a database. The database was initially created using the GIS functionalities, along with a preliminary drawing of the multiple elements and likely boundaries of each land parcel. This was completed based on the observation of orthophoto maps and additional data received by the local government. To simplify the data collection and organization, the intervention area was divided into 19 sub-areas, labelled from A to T, as presented in Figure 2. A single code was assigned to each parcel.

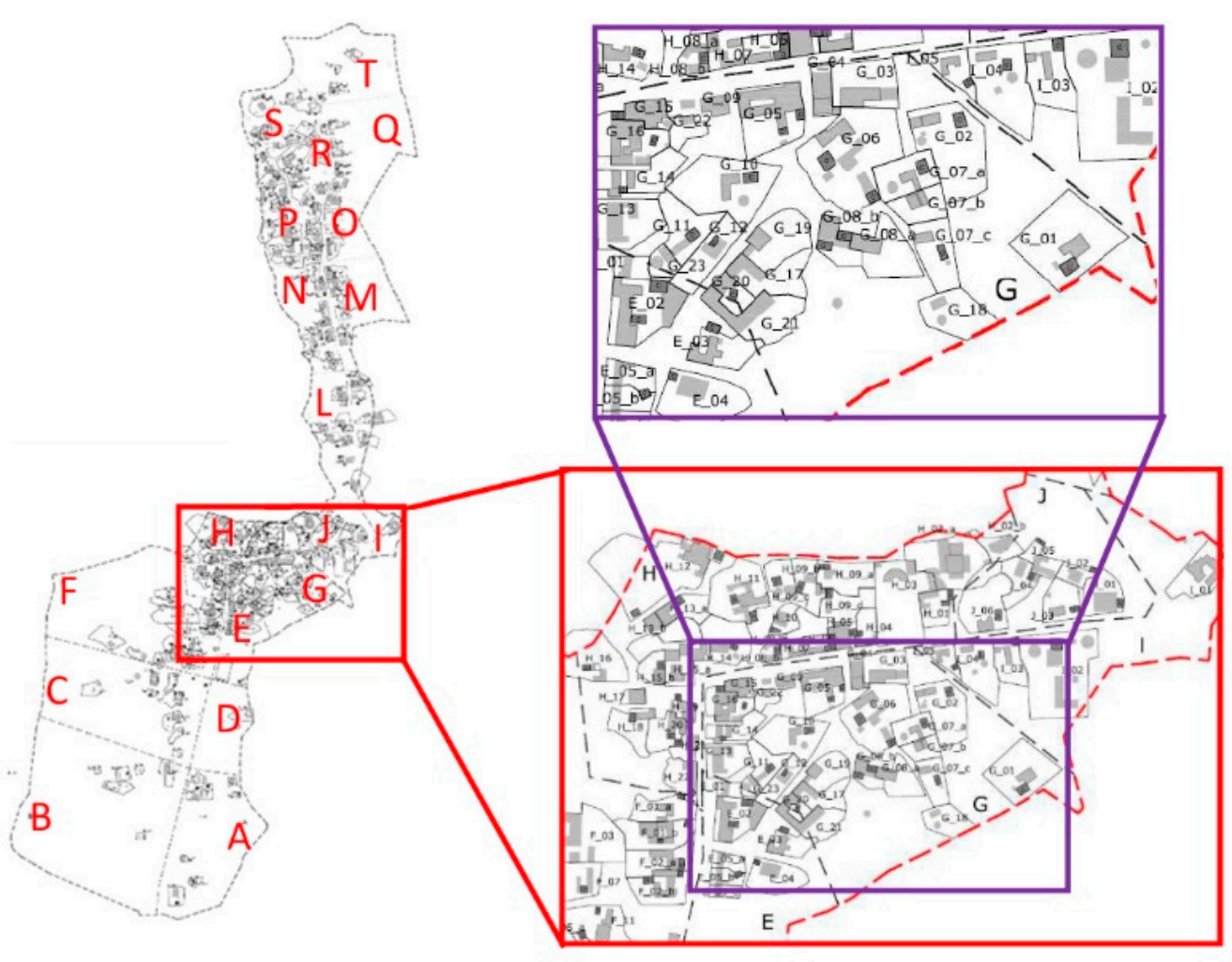

Figure 2. Subdivisions of the planning area A-T. 
In addition to the base map that would be used for the field survey, we created a characterisation form for each parcel. The specifications of each parcel that were recorded included the land use, number of floors, structural condition, construction materials, and other notes. Afterward, all information was synthesised in a table to provide a summary and overview that could be further analysed.

An on-site survey was completed to provide a strong work base for the next step. The spatialization, characterisation, and total area used of each building were recorded. Using this method, an on-site map was developed, along with the parcel's occupants and the boundaries of the different parcel elements. The "users/owners" or their household names were registered. We recorded the existence of cisterns, agriculture areas, toilets, sceptic holes, and other relevant information (Figure 3).
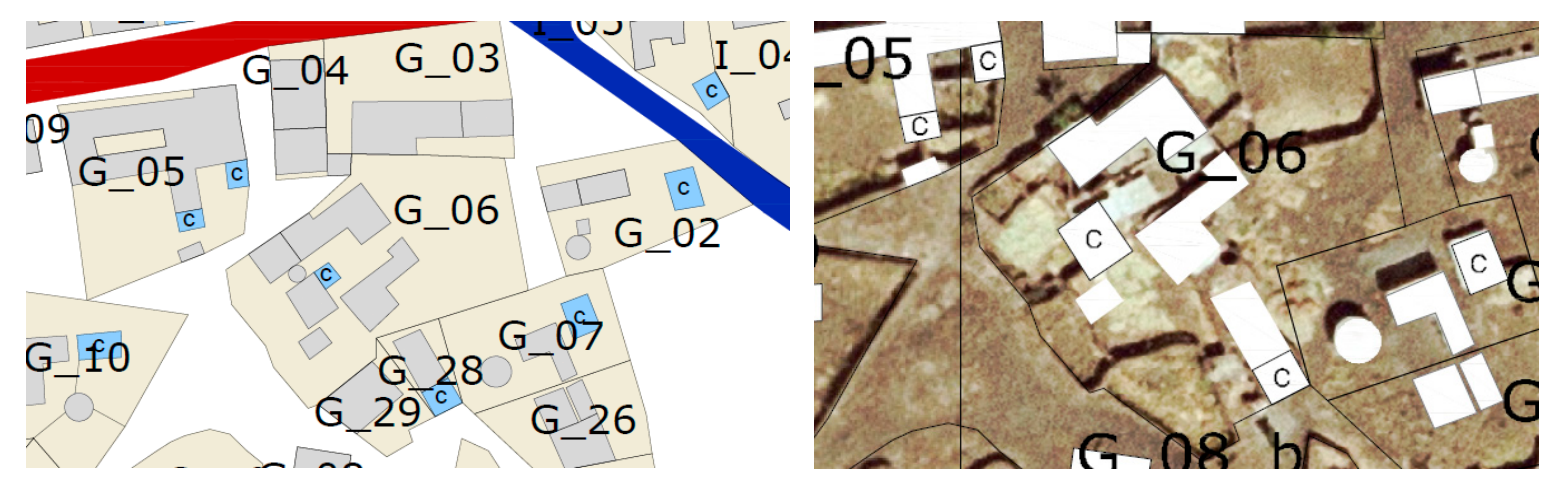

Figure 3. Correction of the cadastral base maps.

Through the field work, we collected the data required to create a cadastral database of the existing occupation with an actualised chart, which included a characterisation sheet for each parcel and a table with all the relevant data (Table 1) to be used for the next step.

The survey was complemented with environmental, morphologic, legal, risk, and social-economic analyses, which were all introduced in the GIS $[33,34]$. The most relevant analyses included in this methodology were (Figure 4):

(1) Environment and risk: hypsometry, slopes and strands exposure, geology and lithology, hydrology, climate, land occupation, erosion, seismic and volcanic risks, and land slide risk.

(2) Socio-economic: population, age and gender distribution, educational level, population structure and employment, and economic activities.

(3) Morphology: structure, building use, number of floors, construction materials, conservation, public spaces, and natural areas.

(4) Legal: territorial management instruments and tenure land model. 
Table 1. Characteristics of the different parcels (extract).

\begin{tabular}{|c|c|c|c|c|c|c|c|c|c|c|c|c|c|}
\hline $\begin{array}{l}\text { Parcel } \\
\text { Code }\end{array}$ & $\begin{array}{c}\text { Parcel } \\
\text { Area }\left(\mathrm{m}^{2}\right)\end{array}$ & $\begin{array}{l}\text { Building } \\
\text { Area }\left(\mathrm{m}^{2}\right)\end{array}$ & $\begin{array}{c}\text { Cistern } \\
\text { Area }\left(\mathrm{m}^{2}\right)\end{array}$ & Use/Activity & Cistern & Agriculture & $\begin{array}{l}\text { Sceptic } \\
\text { Tank }\end{array}$ & Floors & $\begin{array}{l}\text { Conservation } \\
\text { Stage }\end{array}$ & $\begin{array}{l}\text { Building } \\
\text { Materials }\end{array}$ & Owner & $\begin{array}{c}\text { Family } \\
\text { Number }\end{array}$ & $\begin{array}{c}\text { Possession } \\
\text { Title }\end{array}$ \\
\hline A_04 & 502.8 & 80.1 & - & Mix & No & Yes & No & 1 & Good & Concrete Blocks & $\begin{array}{l}\text { José Lopes dos } \\
\text { Santos }\end{array}$ & 1 & $\mathrm{~N}$ \\
\hline B_02 & 788.33 & 58.85 & 35.16 & Residential & Yes & Yes & No & 1 & Reasonable & $\begin{array}{c}\text { Stone/Concrete } \\
\text { Blocks }\end{array}$ & $\begin{array}{c}\text { Manuel Lopes } \\
\text { dos Santos }\end{array}$ & 3 & $\mathrm{~N}$ \\
\hline F_03 & 3279.93 & 674.11 & - & Tourism & Yes & - & Yes & 1 & Excellent & Stone & $\begin{array}{c}\text { Hotel } \\
\text { Montrond } \\
\text { (Maria) }\end{array}$ & - & Y \\
\hline G_06 & 1341.85 & 297.78 & 10.87 & Residential & Yes & Yes & Yes & 1 & Reasonable & Concrete Blocks & $\begin{array}{l}\text { Hernana } \\
\text { Fernandes }\end{array}$ & 13 & $\mathrm{~N}$ \\
\hline N 10 & 415.10 & 21.92 & 12.23 & Residential & Yes & Yes & No & 1 & Bad & Stone & Julia Pires & 3 & $\mathrm{~N}$ \\
\hline
\end{tabular}




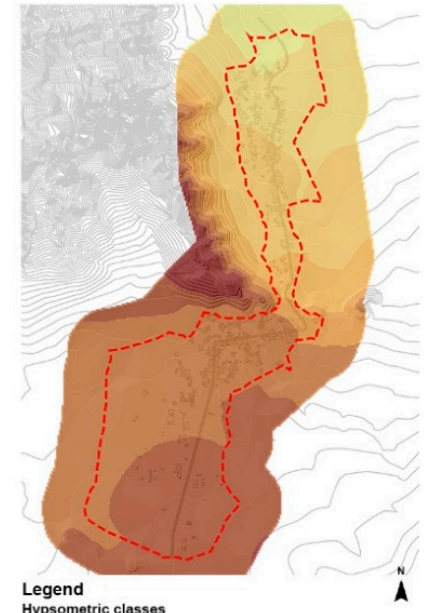

Legend

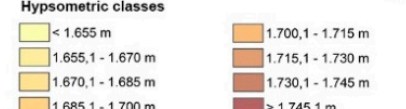

$\square=1.670,1-1.685 \mathrm{~m} \longrightarrow$

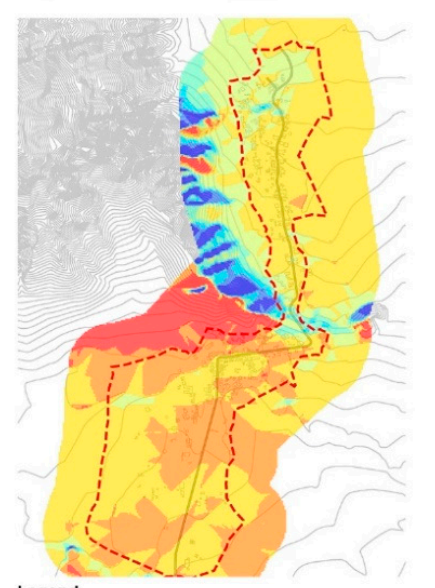

Legend

Solar Radiation W/m2/millions

$\square_{0,85-0.95}^{0.85} \square_{0.95-1.05}^{1,15-1,22}$

$\square_{1,05-1,15}^{0,95-1,05} \underset{>1,32}{1,28-1,32}$

250

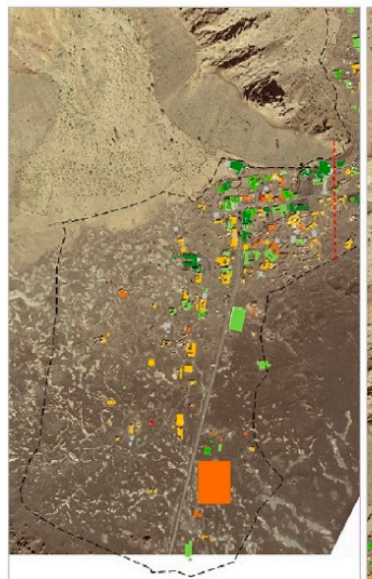

Legend

Building conservation

Excellent

Good

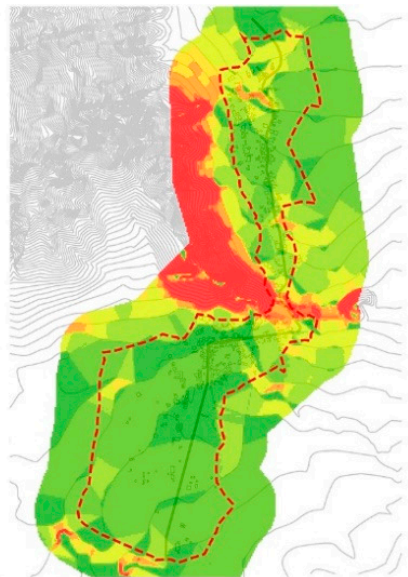

Legend
Slope class

$\underset{<2 \%}{<\text { Slope classes }}<$

$<\%$
$\square^{12,1-15 \%}$

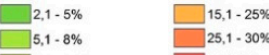

$\square 8,1-12 \%$

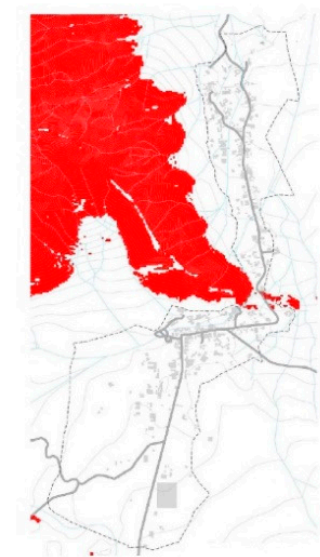

Legend
Soil Erosion

[1] Existing Buildings

Roads
Soil Erosion Risk
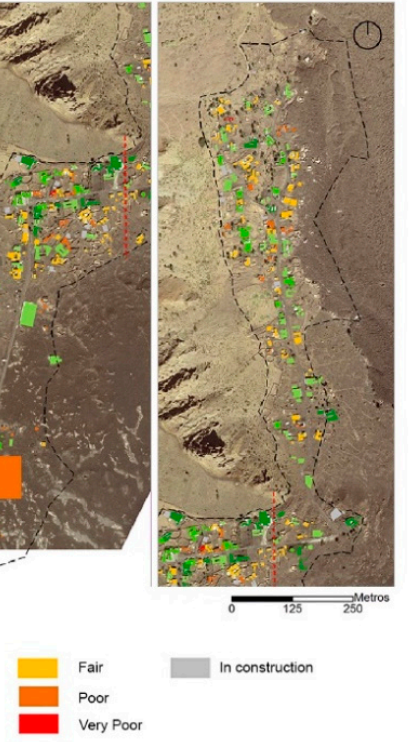
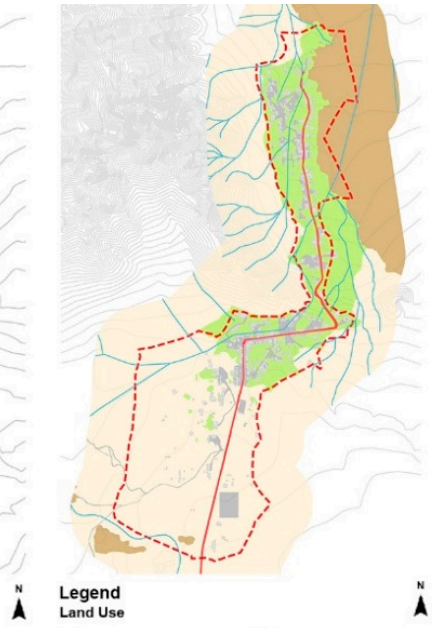

N Legend
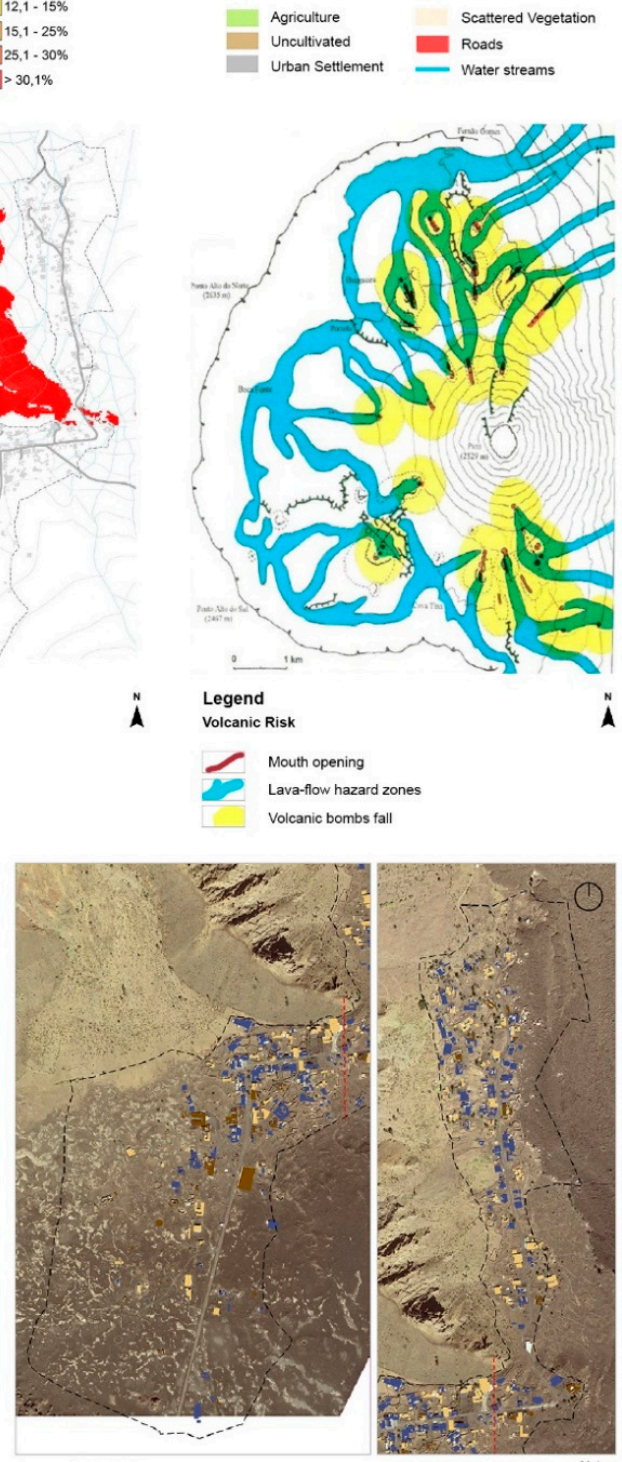

Legend

Building materials

Concrete Blocks

Figure 4. Analysis: environment, risks, legal and morphologic. 


\subsection{Application of Step 2: Design of the Parametric Model}

The analysis of the existing physical components allowed us to conclude that cisterns were present in most (73\%) of the parcels. Assuming this element was a parametric vector, we joined it to another two elements identified via direct observation: the building and the area for agriculture and livestock [17]. According to these assumptions, three different typologies of land occupation were identified: (1) Typology 1 (T1), composed of a building (house), cistern, and a free area with an unspecified use in addition to everyday living; (2) Typology 2 (T2), including the elements of Typology 1 plus an area designated for agriculture or livestock; and (3) Typology 3 (T3), composed only of an area designated for agriculture or livestock.

\subsubsection{Definition of the Physical Components of the Parametric Model}

Using an operational method, the model definition was mostly based on typologies T1 and T2. For each of T1 and T2, the calculation of the total parcel area $(A t)$ was defined as the area used by the parcel occupants for everyday living (Figure 5). For each defined $A t$, we identified the different existing physical components, such as the cistern area $(A c)$, the building area $(A b)$, agriculture and livestock area $(A a)$, and the free area $(A f)$. The $A f$, based on its dimensions in $\mathrm{T} 1$, was adopted as an unknown factor in the proposed parametric model. The $A a$ in T2 was determined from $A c$ and $A b$, and was used as an unknown sub-factor.

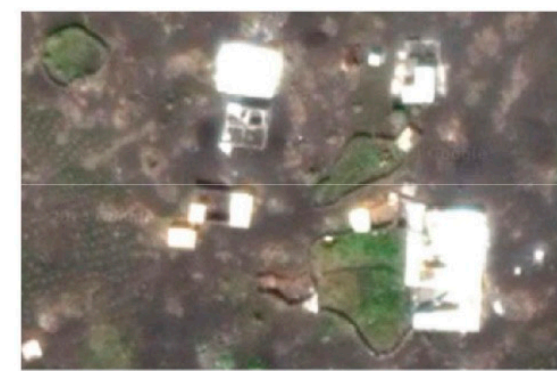

a)

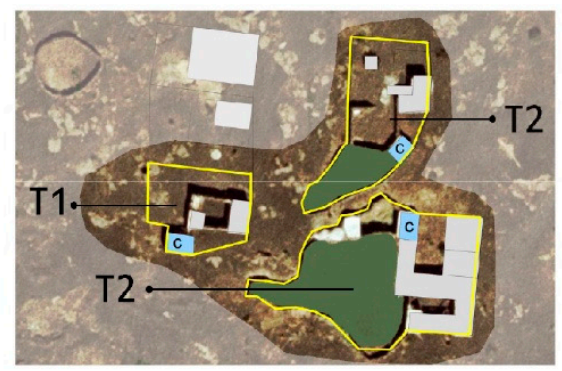

Land Parcel (At)

Cistern area (Ac)

Built-up area (Ae)

Area for agriculture and/or livestock (Aa)

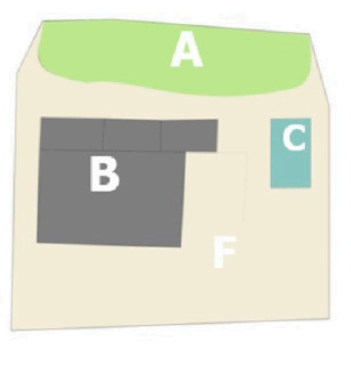

c)

Figure 5. (a) Orthophoto; (b) Typology 1 (T1) and Typology 2 (T2); (c) Schematic identification of existing physical components

\subsubsection{Unknown Factor Calculation: $A f$}

To calculate the unknown factor $A f$, we added together the areas of $A b$ and $A c$ when a cistern was present. If not, we only used $A b$.

$$
S=\sum_{i=1}^{n}(A b+A c) \text { or } S=\sum_{i=1}^{n}(A b)
$$

After obtaining the sums (S), $A f$ was calculated as the difference between $A t$ and its respective $S$, which was calculated for each typology delimited inside the intervention area:

$$
A f=A t-S
$$

Table 2 shows an extract of the Excel sheet created for the data treatment of the different physical components identified in the intervention area. 
Table 2. Areas of the physical components in the different parcels.

\begin{tabular}{ccccccccc}
\hline $\begin{array}{c}\text { Parcel } \\
\text { Code }\end{array}$ & $A t\left(\mathrm{~m}^{2}\right)$ & $\mathrm{C}$ & $A c\left(\mathrm{~m}^{2}\right)$ & $A \boldsymbol{b}\left(\mathrm{m}^{2}\right)$ & $\begin{array}{c}\sum(A b+A c) \\
\left(\mathrm{m}^{2}\right)\end{array}$ & $\begin{array}{c}\text { Agriculture or } \\
\text { Livestock }\end{array}$ & $A \boldsymbol{a}\left(\mathrm{m}^{2}\right)$ & $A f\left(\mathrm{~m}^{2}\right)$ \\
\hline A_05 & 1317.54 & Yes & 39.39 & 276.97 & 315.6 & Yes & 818.27 & $?$ \\
\hline
\end{tabular}

Once we had determined all the $A f$ values, an average $A f\left(A f_{w a}\right)$ was calculated to normalise the multiple values obtained, and determine the standard deviation in terms of the maximum and minimum areas.

Free weighted average area:

$$
A f_{w a}=\sum_{i=1}^{n}(\min <(A f)<\max ) / n
$$

\subsubsection{SUB-Unknown Factor Calculation: $A a$}

The $A a$ was studied non-autonomously, as it was associated with the building proximity and the cisterns. The dimension of the $A a$ was related to the habitational vocation of the occupants of the parcel. As such, the $A a$ of any T2 typology was determined based on the free weighted average area defined as

$$
A a=A t-\sum_{i=1}^{n}\left[(S)+\left(A f_{w a}\right)\right] / n
$$

\subsubsection{Weighted Average Calculation of All Physical Components}

Once we completed the framework of the physical components of the land occupation, the concept of the free weighted average area was applied using the following formulae.

Weighted average land area:

$$
A t_{\text {wa }}=\sum_{i=1}^{n}(\min <(A t)<\max ) / n
$$

Weighted average building area:

$$
A b_{w a}=\sum_{i=1}^{n}(\min <(A b)<\max ) / n
$$

Weighted average cistern area:

$$
A c_{w a}=\sum_{i=1}^{n}(\min <(A c)<\max ) / n
$$

Weighted average agriculture/livestock area:

$$
A a_{m p}=\sum_{i=1}^{n}(\min <(A a)<\max ) / n
$$

The application of the parametric model to the average areas of the existing land occupation resulted in a normalisation as rigorous as possible of the fundamental elements that characterise the new parcels.

\subsection{Application of Step 3: Definition of New Parcels}

Multiple factors influenced the proposal, including those linked to the site, topography, urban morphology, land occupation, environmental, and social elements. According the calculation method in Step 2, three distinct parcels typologies were defined based on parcel use, with the goal of improving living conditions. 


\subsubsection{A-Type Parcel}

A-TYPE parcels included a specific housing typology: parcels in the built-up area with one floor, a cistern area, and with the remaining area considered as a free area. These values were obtained by a weighted average of all the referred components, originating from the framework shown in Table 3.

Table 3. A-type parcel parameters.

\begin{tabular}{cccccc}
\hline A-Type & $\boldsymbol{A} \boldsymbol{b}$ & $\boldsymbol{A c}$ & $\boldsymbol{A f}$ & $\boldsymbol{A} \boldsymbol{a}$ & $\boldsymbol{A t}$ \\
\hline Avarage area & $122.25 \mathrm{~m}^{2}$ & $29.63 \mathrm{~m}^{2}$ & $176.80 \mathrm{~m}^{2}$ & - & $328.68 \mathrm{~m}^{2}$ \\
Used values & $125 \mathrm{~m}^{2}$ & $30 \mathrm{~m}^{2}$ & $175 \mathrm{~m}^{2}$ & - & $330 \mathrm{~m}^{2}$ \\
Ratio & $38 \%$ & $9 \%$ & $53 \%$ & - & $100 \%$ \\
\hline
\end{tabular}

\subsubsection{B-Type Parcel}

This typology included a mixed-typology divided into four components: a building area (usually with one floor), a cistern area, an area for agriculture and/or livestock, and a free area (Table 4).

Table 4. B-type parcel parameters.

\begin{tabular}{cccccc}
\hline B-Type & $A b$ & $A c$ & $A f$ & $A \boldsymbol{a}$ & $A \boldsymbol{t}$ \\
\hline Avarage area & $122.25 \mathrm{~m}^{2}$ & $29.63 \mathrm{~m}^{2}$ & $176.80 \mathrm{~m}^{2}$ & $455.24 \mathrm{~m}^{2}$ & $783.93 \mathrm{~m}^{2}$ \\
Used values & $125 \mathrm{~m}^{2}$ & $30 \mathrm{~m}^{2}$ & $175 \mathrm{~m}^{2}$ & $460 \mathrm{~m}^{2}$ & $790 \mathrm{~m}^{2}$ \\
Ratio & $16 \%$ & $4 \%$ & $22 \%$ & $58 \%$ & $100 \%$ \\
\hline
\end{tabular}

\subsubsection{C-Type Parcel}

This typology only included an area for agriculture and livestock, accounting for $100 \%$ of the parcel area, with the purpose of creating rural ordinated parcels that could be given to owners of typology-A parcels who did not have access to this type of land in their own parcel (Table 5).

Table 5. C-type parcel parameters.

\begin{tabular}{cccccc}
\hline C-Type & $A b$ & $A c$ & $A f$ & $A \boldsymbol{a}$ & $A \boldsymbol{t}$ \\
\hline Average area & - & - & - & $455.24 \mathrm{~m}^{2}$ & $455.24 \mathrm{~m}^{2}$ \\
Used values & - & - & - & $460 \mathrm{~m}^{2}$ & $460 \mathrm{~m}^{2}$ \\
Ratio & - & - & - & $100 \%$ & $100 \%$ \\
\hline
\end{tabular}

To standardise the future land occupation, the urban planning exercise focused on equipment definition if any land was not being used. Based on the multiple analysis process that was performed, multiple categories of land use were defined, with the purpose of planning and controlling the limit of the settlement development. As such, we decided to delineate the urban expansion zone and provide areas for agriculture and livestock.

Before the land use model was created, we standardised the existing parcels' boundaries to simultaneously consolidate the settlement and define the areas required for infrastructure. Finally, in the zones that were identified as empty, we proposed a subdivision of these areas into new habitational parcels and agriculture and livestock parcels, based on the typologies previously defined (Figure 6). 


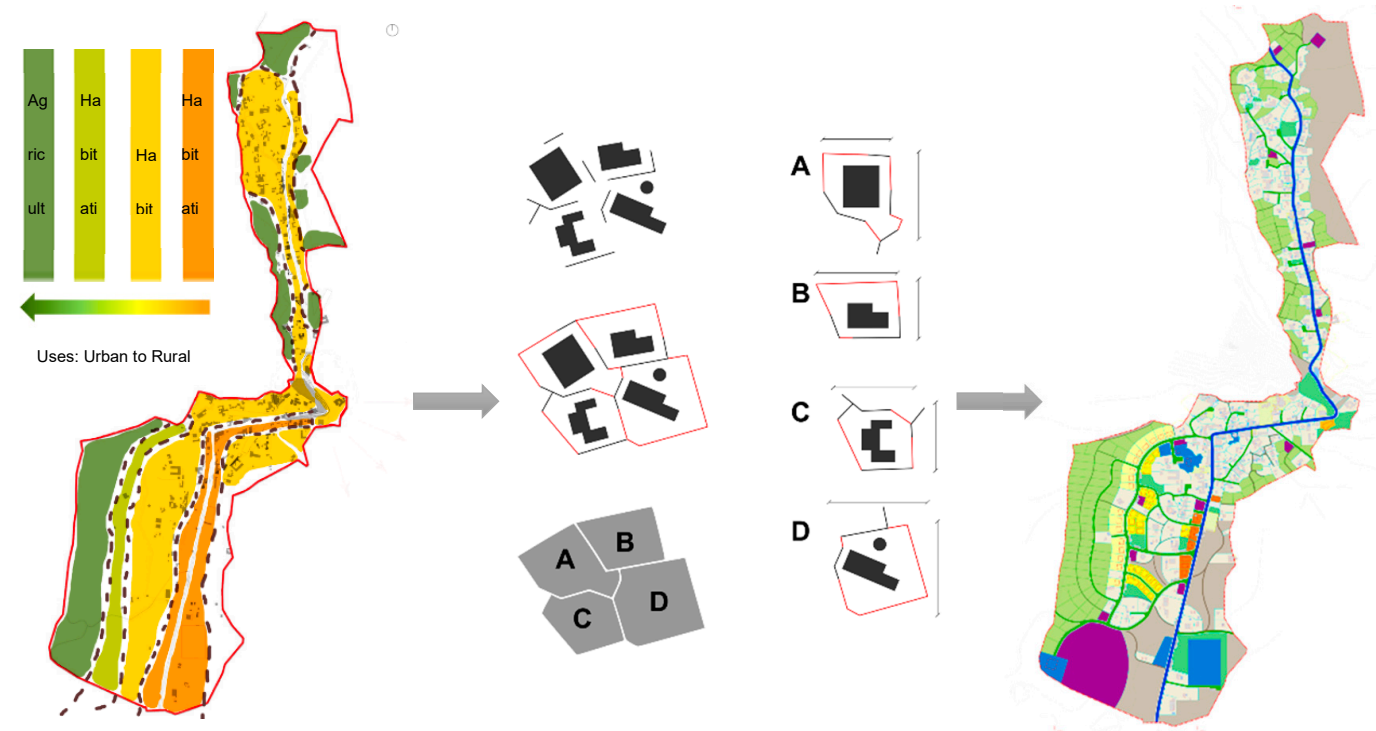

Figure 6. Process scheme.

\subsection{Application of Step 4-Development of the Cadastral Model}

Based on Cape Verde's regulations, a building was characterised based on its administrative and geographic location, and geometric configuration and area, plus each building was assigned a unique numeric code (termed the building identification number) which was required in all public documents. Using this system, and by considering the characteristics in terms of the predominant land use of the intervention area, the areas were classified into two cadastral typologies: urban and rural. According to this division and considering the social characteristics of Chã das Caldeiras, the area was divided in two different townships, Bangaeira (North) and Portela (South). An example of the building and rural registration is provided in Table 6 .

Table 6. Nomenclature adopted to the parcels codification.

\begin{tabular}{ccccc}
\hline Township & Registration of the Rural Building & Registration of the Urban Building & Parcel \\
\hline B & $\mathrm{R}$ & $\mathrm{U}$ & $\mathrm{XX}$ \\
P & $\mathrm{R}$ & $\mathrm{U}$ & $\mathrm{XX}$ \\
P: Portela & & & \\
B: Bangaeira & & & \\
\hline
\end{tabular}

We assigned a code to each existing and proposed parcel according to its use and location. To create a solution for the administration, management, and planning of the intervention area, the boundaries of the existing and future occupation were defined according to the urban parameters, including territory load capacity, land use compatibility, and existing on-site building limitations. Using this method, the cadastral model proposed was transposed into a legal map, along with a list of the urbanistic parameters and the cartesian coordinates to enable the identification of the boundaries, the constitution of the parcels, their geographic location, and their reference code.

\section{Citizen Engagement in the Co-Design}

The inhabitants participated in the entire process of co-design, which provided some rewarding results. The advantage of participation in design is the ability to obtain a series of designs that reflect the real needs of the community, and the community's desires for sharing and interaction. This process also allowed the local authorities to have regular and necessary moments of contact with the population. In view of the expected need for regulation in the occupied land areas and the reconstruction of walls and fences for the transfer of rights between land users, the participation model chosen by the team 
was that of plenary assemblies [35]. Given the economic and social contexts, and for political reasons, all the workshops and summits occurred at the geographic junction of the two settlements [36,37]. The results of the plenary discussions were very positive, so the extant settlements were able to integrate new equipment into their location [38] (Figure 7). Notably, the expectation of regularization of land ownership has helped with the success of the process and its dissemination $[39,40]$.

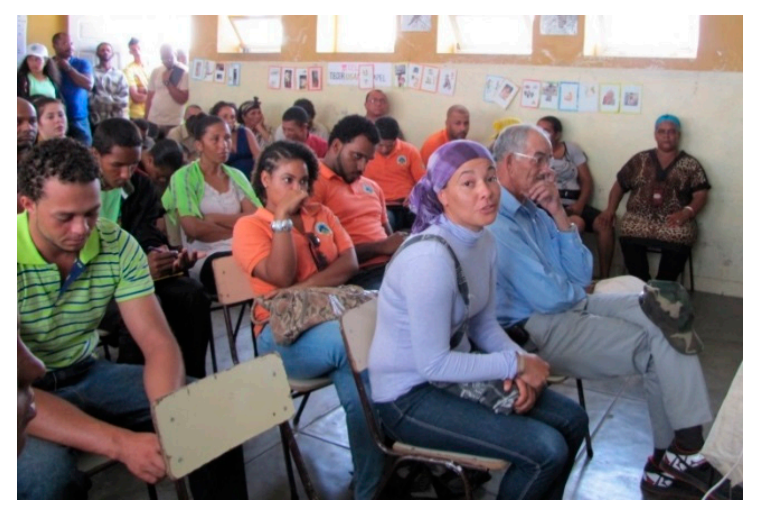

Figure 7. Population plenary assemblies.

\section{Results}

The application of this method resulted in the production of a land ownership database, including a cadastral model, a management register, and maps. The management solution that we obtained allowed the municipality to manage the existing occupancy, uses, classes, and categories of the land areas. Table 7 presents an example of the obtained results.

Table 7. Extract of the management solution obtained with the method created-Land specifications.

\begin{tabular}{cccc}
\hline Parcel Code & Parcel Area $\mathbf{( m}^{\mathbf{2}} \mathbf{~}$ & Land Use Class-Spatial Class & Use Category \\
\hline P_U_1 & 1472.88 & Buildable area-Rural & Tourism area 4.1 \\
P_U_2 & 570.24 & Buildable area-Rural & Tourism area 4.1 \\
P_U_3 & 731.67 & Buildable area-Rural & Residential area 1.1 \\
P_U_4 & 466.23 & Buildable area-Rural & Residential area 1.1 \\
P_U_5 & 605.48 & Buildable area-Rural & Residential area 1.1 \\
$\ldots$ & $\ldots$ & $\ldots$ & $\ldots$ \\
B_U_103 & 203.21 & Buildable areas-Rural & Residential area 1.1 \\
B_U_104 & 379.06 & Non-built areas-Agriculture/livestock & Agricultural area 6.5 \\
B_U_105 & 900.00 & Channel and Equipment-Technical equipment & Infrastructure area 10.2 \\
\hline
\end{tabular}

The cadastral map we developed using this method accurately depicts the land occupation, allowing for data treatment and planning regarding the existing occupancy. Figure 7 shows the obtained georeferenced map that was supported using GIS. The accurate mapping of the existing land occupation allows the municipality to understand the existing situation and to further manage occupation, including rearranging or re-ordering it while being fair to all involved. An example of its potential is the management of the existing parcel areas and the reordering of the boundaries of the existing parcels to create an area to guarantee needed infrastructure and equipment. Table 8 provides an extract of an area where adjustments were made to the existing parcels limits to provide space for utilities, representing a transparent and participative process with the owners of the parcels [41]. 
Table 8. Extract of the management board obtained by the method adopted-parcels limit adjustments.

\begin{tabular}{|c|c|c|c|c|}
\hline \multirow[t]{2}{*}{ Parcels Code } & \multirow{2}{*}{$\begin{array}{l}\text { Assignment Area to } \\
\text { Roadways Hitches }\left(\mathrm{m}^{2}\right)\end{array}$} & $\begin{array}{l}\text { Area to Roadway } \\
\text { Hitches }\left(\mathrm{m}^{2}\right)\end{array}$ & $\begin{array}{l}\text { Area to Roadway } \\
\text { Hitches }\left(\mathrm{m}^{2}\right)\end{array}$ & \multirow[t]{2}{*}{ Observations } \\
\hline & & Increase & Decrease & \\
\hline P_U_21 & 13.02 & 23.59 & - & Road/Public Domain \\
\hline P_U_22 & 88.75 & 20.28 & 21.06 & Road, sidewalk and P_U_26/Public Domain \\
\hline P_U_23 & 1.30 & - & 4.92 & Road, sidewalk and P_U_26 \\
\hline P_U_24 & - & 7.15 & - & Public Domain \\
\hline P_U_25 & - & 11.61 & - & Public Domain \\
\hline
\end{tabular}

The correct identification of land uses and occupation allowed the creation of new parcels. According to the parametric methodology adopted, parcels were created according to the existing need and the existing parcel areas, in order to plan an expansion area based on the verified occupation areas (Figure 8).

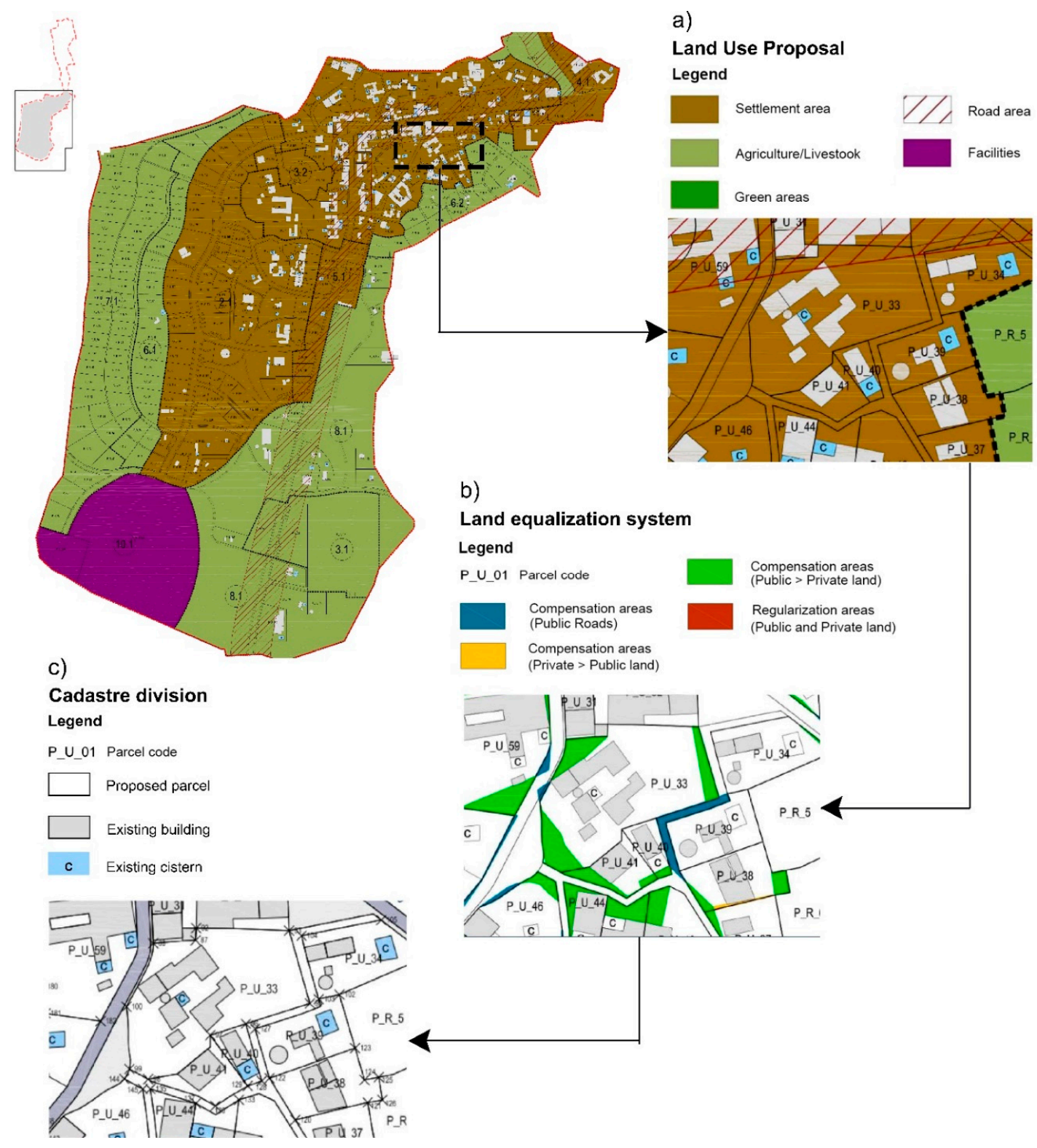

Figure 8. (a) Land use proposal; (b) Land equalization system; (c) Cadastre division. 
This detailed information enabled the municipality to access the building index of any parcel and control the creation of new buildings, preventing uncontrolled expansion inside the settlements.

\section{Conclusions}

This study establishes the land transformation process from an informal model to a formal one and analyzes the influence of the parametric design in the built-in cadastral model solution. The pursuit of compact urban areas helps the management system to ensure the minimum living conditions in a transparent and balanced social solution.

The experimental process reveals complex insights into how change can be fostered and supported in the context of the transformation of an informal area into a formal one.

The method and process carried out and its application accepted by the public entity and the local population show the viability of the method to answer to the designation of the existing morphology of the settlement and to the non-existence of formal planning.

The intervention permitted the composition of a process of fair management of access and use of land. It permitted the creation of a detailed and complete database acceptable to a strong discussion and fair management from the existing situation of land occupation, and a future proposal for the settlement to be transformed into a formal area.

This method leads to high, detailed, and fair planning for the intervention area and created a basis for the management and control of land occupation avoiding future unplanned uses in the Chã de Caldeiras settlement. It also ensured a regulated expansion that is concerned with the needs of the population in terms of infrastructure of services as well as equipment planning and programming.

The research method developed allows for the possibility of being applied to the transformation of informal settlements or extended formal urban areas in other geographic contexts where there are difficulties in the tenure of the land and with the context of constraints to the development and acceptance of territorial management models that can be implemented. Also, the population being involved in the process of co-designing the transformation of the settlements, reinforcing the modeling governance, reflects in a better way the answers to the real needs of the community, who can be incorporated as part of future guide lines to sustainable urban planning.

In future research, other advantages of the method are that it is possible to explore the development of a registry of land use and the data of the users of the public infrastructure networks, and also to support a facilities and equipment program.

Author Contributions: M.A. and F.P. have contributions to conception and design the research, acquisition of data, analysis and interpretation of data; drafting the article and revising it critically for important intellectual content; A.M., N.V. and A.R.A. have a contribution in the analysis and interpretation of data and in drafting the article and revising it critically for technical content; All authors have a contribution in the final approval of the version of the paper to be published.

Funding: This research received no external funding.

Acknowledgments: The second and four authors thanks to the Portuguese Fundação para a Ciência e Tecnologia (FCT) for the financial support through Ph.D. Fellowship.

Conflicts of Interest: The authors declare no conflicts of interest.

\section{References}

1. Durovic, R.; Nikolic, G. Aspects of urban and rural land consolidation and accurancy problems of GIS database for the needs of spacial planning documents. Agric. For. 2016, 62, 125-138.

2. United Nations (UN). Transforming Our World: The 2030 Agenda for Sustainable Development; United Nations (UN): New York, NY, USA, 2015.

3. Abrams, C. Man's Struggle for Shelter in an Urbanizing World; M.I.T. Press: Cambridge, MA, USA, 1964.

4. Payne, G.K. Urban Housing in the Third World; Routledge Kegan \& Kegan Paul: London \& Boston, UK, 1977.

5. Steyn, G. Sustainable African Settlement: Profiling a Vision; Tshwane University of Technology: Pretoria, South Africa, 2003. 
6. Turner, J. Uncontrolled urban settlement: Problems and policies. In Urbanization: Development Policies and Planning, International Social Development Review No. 1; United Nations: New York, NY, USA, 1968.

7. Amado, M.P.; Ramalhete, I.; Amado, A.R.; Freitas, J.C. Regeneration of informal areas: An integrated approach. Cities 2016, 58, 59-69. [CrossRef]

8. Anguita, P.M. Desarrolo Rural Sostenible; McGraw Hill: Madrid, Spain, 2006.

9. Holland, B. Typologies of nation urban policy: A theoretical analysis. Cities 2015, 48, 125-129. [CrossRef]

10. United Nations (UN). Open working group proposal for sustainable development goals. In Full Development of the Open Working Group of the General Assembly on Sustainable Development Goals is Issued as Document A/68/970; United Nations: New York, NY, USA, 2018. Available online: http://undocs.org/A/68/970 (accessed on 25 April 2018).

11. Imbroscio, D. From redistribution to ownership: Toward the built environment in advanced capitalist countries. Politics Soc. 2013, 6, 265-295. [CrossRef]

12. Todes, A. Urban Growth and Strategic Spatial Planning in Johannesburg, South Africa. Cities 2012, 29, 158-165. [CrossRef]

13. Wong, J.M.W.; Ng, S.T.; Chan, A.P.C. Strategic planning for the sustainable development of the construction industry in Hong Kong. Habitat Int. 2010, 34, 256-263. [CrossRef]

14. Roberts, P.; Sykes, H. (Eds.) The evolution and purpose of urban regeneration. In Urban Regeneration: A Handbook; Sage: London, UK, 2000; pp. 9-36.

15. Paulsson, J.; Paasch, J. The Land Administration Domain Model—A literature survey. Land Use Policy 2015, 49, 546-551. [CrossRef]

16. Allaghan, E.; Colton, J. Building sustainable and resilience communities: A balancing of community capital. Environ. Dev. Sustain. 2008, 10, 931-942. [CrossRef]

17. Amado, M. Wall-Up: Method to the regeneration of settlements and housing in the Developing World. Sustain. Cities Soc. 2018, 41, 22-34. [CrossRef]

18. Amado, M.; Ramalhete, I.; Amado, A.R.; Freitas, J.C. Inclusive housing program: The case of Oé-Cusse region in East Timor. Front. Archit. Res. 2017, 6, 74-88. [CrossRef]

19. Aydinoglu, A.; Bovkir, A. Generic land registry and cadastre data model supporting interoperability based on International Standards for Turkey. Land Use Policy 2017, 68, 59-71. [CrossRef]

20. United Nations Economic Commission for Europe (UN-ECE). Land Administration Guidelines-With Special Reference to Countries in Transition; United Nations: New York, NY, USA, 1996; ISBN 92-1-116644-6.

21. Uzun, B.; Simsek, N.C. Upgrading of illegal settlements in Turkey; The case of North Ankara Entrance Urban Regeneration Project. Habitat Int. 2015, 49, 157-164. [CrossRef]

22. Steudler, D.; Rajabifard, A.; Williamson, I.P. Evaluation of land administration systems. Land Use Policy 2004, 21, 371-380. [CrossRef]

23. Uzun, B.; Cete, M. A model for solving informal settlement issues in developing countries. In Proceedings of the FIG Working Week 2004, Athens, Greece, 22-27 May 2004. Available online: https://www.fig. net/resources/proceedings/fig_proceedings/athens/papers/ts24/TS24_1_Uzun_Cete.pdf (accessed on 24 April 2018).

24. Kuyucu, T.; Unsal, Q. Urban renewal in Instambul 'Urban regeneration' as state-led property transfer: An analysis of two cases of urban renewal in Instambul. Urban Stud. 2010, 47, 1479-1499. [CrossRef]

25. Dundar, O. Models of urban transformation informal housing in Ankara. Cities 2001, 18, 391-401. [CrossRef]

26. Lemmen, C.; Oosterom, P.; Bennett, R. The Land Administration Domain Model. Land Use Policy 2015, 49, 535-545. [CrossRef]

27. International Federation of Surveyors (FIG). Statement on the Cadastre; International Federation of Surveyors (FIG): Copenhagen, Denmark, 1995; ISBN 0-644-4533-1.

28. Conzen, M.P. Town-plan analysis in an American seting: Cadastral processes in Boston and Omaha, 1630-1930. In The Built Form of Western Cities; Salter, T.R., Ed.; Leicester University Press: Leicester, UK, 1990; pp. 142-170.

29. Corlazzoli, M.; Fernandez, O. SPOT 5 Cadastral validation project in Izabal, Guatemala. Int. Arch. Photogramm. Remote Sens. Spat. Inf. Sci. 2004, 35, 291-296.

30. Ali, Z.; Shakir, M. Implementing GIS-Based Cadastral and Land Information System in Pakistan. J. Settl. Spat. Plan. 2012, 3, 43-49. 
31. Abbott, J. The use of GIS in informal settlement upgrading:its role and impact on the community and on local government. Habitat Int. 2003, 27, 575-593. [CrossRef]

32. Rao, S.S.; Sharma, J.; Rajashekar, S.S. Assessing usefulness of high-resolution satellite imagery (HRSI) for re-survey of cadastral maps. ISPRS Ann. Photogramm. Remote Sens. Spat. Inf. Sci. 2014, 2, 133-143. [CrossRef]

33. Ali, Z. Assessing Usefulness of High-Resolution Satellite Imagery (HRSI) in GIS-based Cadastral Land Information System. J. Settl. Spat. Plan. 2012, 3, 93-96.

34. Abbott, J. Use of spatial data to support the integration of informal settlements into formal city. Int. J. Appl. Earth Obs. Geoinf. 2001, 3, 267-277. [CrossRef]

35. Reed, M.G. Power relations and community-based tourism planning. Ann. Tour. Res. 1997, $24,566-591$. [CrossRef]

36. Birkeland, J. Positive development and assessment, Smart Sustainability. Built Environ. 2014, 3, 4-22.

37. Cilliers, P. Framework for understanding complex systems. In Complexity Theory and Management of Networks; Adriani, P., Passiante, G., Eds.; World Scientific: Singapore, 2004; pp. $23-27$.

38. Rittel, H.; Webber, M. Dilemmas in a General theory of planning. Policy Sci. 1973, 4, 155-169. [CrossRef]

39. Yu, J.-H.; Kwon, H.R. Critical Success factors for urban regeneration projects. Int. J. Proj. Manag. 2011, 29, 889-899. [CrossRef]

40. UN-Habitat. Global Report on Human Settlements 2011: Cities and Climate Change; Earthscan Ltd.: London, UK, 2011.

41. New Economics Foundation. Participation Works! 21 Techniques of Community Participation for the 21st Century; New Economics Foundation: London, UK, 1998.

(C) 2018 by the authors. Licensee MDPI, Basel, Switzerland. This article is an open access article distributed under the terms and conditions of the Creative Commons Attribution (CC BY) license (http:/ / creativecommons.org/licenses/by/4.0/). 